Didaktik : Jurnal IImiah PGSD STKIP Subang, ISSN Cetak : 2477-5673 ISSN Online : 2614-722X

Volume VI Nomor 01, Juni 2020

\title{
EFEKTIFITAS IMPLEMENTASI PEMBELAJARAN DARING (FULL ONLINE) DIMASA PANDEMI COVID- 19 PADA JENJANG SEKOLAH DASAR DI KABUPATEN SUBANG
}

\author{
Acep Roni Hamdani ${ }^{1}$, Asep Priatna ${ }^{2}$ \\ 1 Universitas Pasundan, ${ }^{2}$ STKIP Subang \\ 1acepronihamdani@unpas.ac.id, 2aseppriatna064@gmail.com
}

\begin{abstract}
This research is motivated by the existence of full online learning (full online) as a result of Covid-19, it is rumored that online learning is less effective, because there is no maximum preparation in terms of regulation, field implementation, and also students, as well as various supporting infrastructure for online learning Therefore, researchers have a desire to test the effectiveness of learning, because there should be no learning content lost in the middle of this pandemic. The research method used was a survey method, with the instrument used was a questionnaire, which was distributed to 80 random elementary school teachers in Subang Regency. Based on the results of the study the effectiveness of learning from the 8 indicators studied is around $66.97 \%$.
\end{abstract}

Keywords: Effectiveness of Full Online Learning, Covid Pandemic 19, Elementary Schools

\begin{abstract}
ABSTRAK
Penelitian ini dilatarbelakangi oleh adanya pembelajaran daring penuh (full online) sebagai dampak dari Covid-19, beredar kabar bahwa pembelajaran daring kurang efektif dilakukan, dikarenakan belum ada persiapan maksimal dari segi regulasi, pelaksana dilapangan, dan juga siswa, serta berbagai infrastruktur pendukung pembelajaran daring, oleh karena itu peneliti memiliki keinginan untuk menguji tingkat efektifitas pembelajaran, dikarenakan tidak boleh ada muatan pembelajaran yang hilang ditengah pandemi ini. Metode penelitian yang digunakan yaitu metode survei, dengan instrument yang digunakan yaitu angket, yang disebarkan kepada 80 orang guru sekolah dasar secara acak di Kabupaten Subang. Berdasarkan hasil penelitian tingkat efektifitas pembelajaran dari 8 indikator yang diteliti yaitu sekitar $66,97 \%$.

Kata Kunci : Efektifitas Pembelajaran Daring Penuh, Pandemi Covid 19, Sekolah Dasar

\section{A. Pendahuluan}

Pendidikan adalah salah garda terdepan untuk memajukan sebuah bangsa, tanpa ada pendidikan yang bagus maka perkembangan bangsa

kedepan hanya tinggal isapan jempol semata, bahkan secara gambling bapak bangsa Vietnam membuat sebuah pernyataan sebagai tolak ukur fondasi pentingnya pendidikan yaitu
\end{abstract}


Didaktik : Jurnal IImiah PGSD STKIP Subang, ISSN Cetak : 2477-5673 ISSN Online : 2614-722X Volume VI Nomor 01, Juni 2020

"No Teacher, No Education, No Education, No Economic and Social Development (Luthfi, 2013). Dari pernyataan tersebut dijelaskan secara tersurat bahwa tanpa ada pendidikan tidak akan mungkin ada perkembangan ekonomi dan sosial. Pendidikan pula memiliki tanggungjawab untuk mengembangkan karakter anak bangsa, karena salah satu tugas dari pendidikan yaitu untuk mewariskan nilai-nilai luhur bangsa dan para leluhur. Walaupun demikian kita harus tetap terbukan untuk melakukan perubahan, menyesuaikan dengan kemajuan dan perkembangan dunia, sehingga kita tidak "picik" memandang dunia dengan globalisasinya.

Berdasarkan kepada pandangan di atas, ada hal krusial yang harus diambil oleh guru ditengah pandemi covid 19 yang sedang melanda dunia, khususnya Indonesia. Berdasarkan data dari Kemendikbud Tahun 2020 bahwa banyaknya siswa yang terdampak covid 19 sehingga mengharuskan mereka belajar di rumah yaitu sebanyak, Sekolah Dasar dan Sederajat sebanyak : 28, 6 Juta, Sekolah Menengah Pertama dan Sederajat sebanyak : 13, 1 Juta, Sekolah Menengah Atas dan
Sederajat sebanyak : 11,3 Juta, dan Pendidikan Tinggi sebanyak : 6,3 Juta (Kemendikbud, 2020). Dari sekian banyak siswa yang terdampak tidak mungkin dibiarkan begitu saja, pembelajaran dan pendidikan harus tetap dilanjutkan walaupun ada berbagai kekurang dan keterbatasan yang harus dihadapi.

Kekurangan dan keterbatasan yang harus dihadapi oleh guru diantanya yaitu: 1) guru tidak berpikiran secepat ini harus menggunakan pembelajaran secara full online, walaupun ada upaya ke arah tersebut, namun tidak terpikirkan akan secepat ini; 2) tidak semua guru memiliki keterampilan literasi digital yang sama, ada guru yang relative lebih mampu beradaptasi, namun ada pula yang tidak mampu beradaptasi, sehingga mereka mengalami kesulitan untuk pembelajaran secara daring; 3) tidak semua guru dan siswa memiliki perangkat minimal yang bisa digunakan, sehingga pembelajaran daring sulit untuk dilakukan; 4) Kualitas koneksi dan ketersidaan paket data yang masih terbatas, dan membutuhkan biaya yang besar, sehingga hal ini menjadi kendala.

Berbagai kendala tersebut ada sebagian yang sudah bias 
Didaktik : Jurnal IImiah PGSD STKIP Subang, ISSN Cetak : 2477-5673 ISSN Online : 2614-722X Volume VI Nomor 01, Juni 2020

diantisipasi, namun ada pula yang masih menjadi polemic ditengah pandemi saat ini. Kita akui bahwa dengan adanya pandemi ini telah mendorong percepatan penerapan teknologi dalam dunia pendidikan, dan dengan pesatnya perkembangan TIK mendorong berbagai stake holder untuk memanfaatkan system Elearning mulai dari yang sederhana sampai yang kompleks untuk meningkatkan efektifitas dan efesiensi penggunaannya dalam pendidikan.

Berdasarkan hasil penelitian yang dilakukan oleh Dewi (2020) pada beberapa sekolah dasar di Salatiga menunjukan bahwa beberapa kendala di atas tidak ditemui secara berarti pada siswa sekolah dasar, dan kemunculannya hanya sedikit sekali. Bahkan dapat disimpulkan bahwa pembelajaran dari yang dilakukan di sekolah dasar dengan metode pembelajaran daring penuh dapat berjalan dengan baik, serta indikator kompetensi yang dituangkan pada Rencana Pelaksanaan Pembelajaran dapat dicapai dengan baik. Namun permasalahan yang muncul yaitu pada siswa kelas 1 yang belum bisa menggunakan gawai, namun hal itu dapat diselesaikan dengan adanya pendampingan dari orang tua siswa.
Hal tersebut di atas agak sedikit berbeda dengan hasil penelitian yang dilakukan oleh Rosalin (2020) dari kementrian PPPA terhadap siswa dari 29 Provinsi, adapun hasil yang dapat diambil adalah sebagai berikut: 1) $58 \%$ anak memiliki perasaan yang tidak menyenangkan selama menjalani kebijakan belajar di rumah; 2)38\% anak berpendapat bahwa sekolah belum memiliki program yang baik dalam menerapkan kegiatan belajar di rumah.

Berdasarkan kedua hasil penelitian tersebut ada sedikit perbedaan terhadap pelaksanaan pembelajaran secara dari yang dilkakukan di sekolah. Berangkan dari ada dikotomi tersebut, maka peneliti tertarik untuk melakukan penelitian dengan judul "Persepsi Guru Terhadap Implementasi Pembelajaran Daring (Full Online) di Kabupaten Subang".

\section{B. Metode Penelitian}

Metode penelitian yang digunakan dalam penelitian ini yaitu metode penelitian survei. Metode Penelitian jenis survei digunakan untuk memecahkan masalah dalam skala besar,dan terjadi secara factual dengan menggunakan sampel 
Didaktik : Jurnal IImiah PGSD STKIP Subang, ISSN Cetak : 2477-5673 ISSN Online : 2614-722X Volume VI Nomor 01, Juni 2020

tertentu (Widodo, 2008). Alsa (2004:20) mengemukakan bahwa rancangan survey adalah prosedur penelitian yang mana peneliti melaksanakan survei atau memberikan angket dengan skala tertentu pada satu sampel untuk menggambarkan sikap, opini, perilaku, atau karakteritik responden. Dari hasil survei ini, peneliti membuat pandangan tentang kecenderungan yang ada dalam populasi.

Berdasarkan

pemaparan

pendapat dari para ahli di atas maka dapat diambil kesimpulan bahwa penelitian survei adalah metode penelitian yang mengkaji populasi dengan menggunakan metode sampel yang memiliki tujuan untuk mengetahui perilaku, karakteristik, dan membuat deskripsi serta generalisasi yang ada dalam populasi tersebut. Pada penelitian ini sampel yang digunakan yaitu sebanyak 80 orang guru yang diambil secara acak di kabupaten Subang dengan menggunakan angket skala likert.

\section{Hasil Penelitian dan Pembahasan}

Penelitian ini dibagi menjadi beberapa hal yang dijadikan pembahasan, untuk lebih memfokuskan hasil penelitian, maka peneliti membagi menjadi beberapa hal yang dibahas menjadi sebagai berikut.

1. Kenyamanan Pembelajaran Masa Pandemi

Kenyamanan

dalam pembelajaran daring merupakan suatu keharusan, tanpa adanya kenyamanan maka atmosfir pembelajaran yang bermakna tidak akan terjadi, kenyamanan ini harus dirasakan oleh dua subjek, baik guru maupun murid sehingga akan terjadi kolaborasi kolektif yang utuh antara guru dengan siswa. Berdasarkan hasil survei tingkat kenyamanan pembelajaran yang dirasakan oleh guru, sekaligus mewakili tingkat kenyamanan siswa yaitu sebesar $59,21 \%$ menyatakan nyaman, sedangkan sisanya 40,79 $\%$ merasa tidak nyaman dengan pembelajaran daring.

Hal tersebut jika digali lebih dalam dapat terungkap bahwa dengan adanya rumah belajar, TVEdukasi dapat menjadi jembatan untuk guru dan sekolah yang belum memiliki tenaga IT yang mumpuni, walaupun ada sebagian sekolah yang sudah memiliki LMS (Learning Management System) tersendiri. Beberapa sekolah yang tidak 
Didaktik : Jurnal IImiah PGSD STKIP Subang, ISSN Cetak : 2477-5673 ISSN Online : 2614-722X

Volume VI Nomor 01, Juni 2020

memiliki LMS secara mandiri

dikarenakan selain keterbatasan tenaga IT, juga disebabkan oleh ada biaya yang harus dikeluarkan untuk melakukan penyewaan server system LMS. Hal ini sependapat dengan Muazizah (2016) yang menyebutkan bahwa pengembangan LMS tersendiri membutuhkan tenaga IT yang mumpuni dan pembiayaan server yang tidak sedikit.

2. Kemampuan Literasi Digital Guru

Kemampuan literasi digital adalah sebuah kemampuan untuk mendapatkan, memahami, dan menggunakan informasi yang berasalah dari berbagai sumber dalam bentuk digital (Gilster, 1997). Dengan adanya UU No. 14 Tahun 2005 tentang Guru dan Dosen, seorang guru profesional dituntut bukan hanya menguasai tentang pencarian informasi digital, tetapi juga harus menguasai tentang pembuktian keabsahan informasi tersebut. Berdasarkan hasil survei kepada guru diperoleh informasi bahwa kemampuan literasi digital mereka secara kolektif adalah $65,78 \%$ menguasai literasi digital, terutama yang berhubungan dengan pembelajaran daring.
Sedangkan sisanya $34,22 \%$ mengalami kesulitan dalam menggunakan pembelajaran daring.

Beberapa upaya sudah dilakukan oleh pemerintah untuk meningkatkan kemampuan literasi digital guru, salah satu diantaranya yaitu dengan mendorong penggunaan Dana Bos untuk pembelian perangkat digital yaitu Laptop, sehingga lambat laun para guru tidak gagap teknologi. Selain hal itu dengan adanya pembelajaran Guru Pembelajar (GP) dan PKP (Peningkatan Kompetensi Pembelajar) dengan moda daring, dan daring kombinasi bertujuan untuk meningkatkan kemampuan literasi digital guru, yang nantinya dapat ditransformasikan kepada siswa.

3. Tingkat Adaptasi Siswa terhadap Pembelajaran

\section{Pandemi Covid-19 selain} sebagai musibah, juga ada hikmah yang bias kita ambil, salah satu hikmahnya dengan mengharuskan kita tinggal dirumah, sementara pembelajaran harus tetap berlangsung. Menteri Pendidikan dan Kebudayaan (Mendikbud) Nadiem Makarim memutuskan, 
Didaktik : Jurnal IImiah PGSD STKIP Subang, ISSN Cetak : 2477-5673 ISSN Online : 2614-722X

Volume VI Nomor 01, Juni 2020

seluruh proses pembelajaran anak usia sekolah dilakukan melalui pembelajaran jarak jauh (PJJ) atau daring selama masa darurat Covid19. Memang tidak semua anak dapat menjalani secara konsisten pembelajaran daring karena berbagai keterbatasan. Misalnya, ketiadaan fasilitas gawai (ponsel, laptop, dan tablet), rendahnya pemahaman tentang media digital, terbatasnya kemampuan membeli pulsa, dan keterbatasan sinyal. Namun, hampir sebagian besar siswa telah merasakan pembelajaran daring.

Mendikbud

pembelajaran daring menyebut proses beradaptasi dengan teknologi. Adaptasi dengan teknologi bagi anak-anak adalah hal yang jauh lebih mudah. Apalagi, saat ini sekolah berhadapan dengan generasi Z. Generasi yang sangat lekat dan akrab dengan gawai atau teknologi digital. Karena itu, sebenarnya anak-anak lebih mudah beradaptasi untuk menggunakan teknologi. Adaptasi teknologilah yang kemudian mendorong anak-anak untuk mudah bermigrasi ke era industri 4.0. Selama ini mungkin anak-anak belum sepenuhnya menyadari bahwa era industri 4.0 membuat efisiensi waktu dan tenaga kerja.

Dalam hal ini, anak tidak harus pergi ke sekolah dengan menggunakan moda transportasi, tapi dapat langsung melalui online ketika belajar. Apalagi di tengah pandemi Covid-19, teknologi menjadi penghubung utama dalam proses belajar. Dunia maya yang selama ini sudah dijelajahi anakanak menjadi dunia yang benarbenar hadir sebagai sebuah proses pembelajaran. Pembelajaran tatap muka dengan bantuan teknologi internet.

Berdasarkan hasil survei yang menyatakan bahwa siswa merasa nyaman menggunakan pembelajaran daring yaitu 65,78 \%, sedangkan sisanya yang merasa kesulitan sekitar 34,22 \%, hal ini sudah dapat diduga dikarena siswa sekarang sudah banyak yang melek teknologi.

4. Kecukupan Perangkat

Pembelajaran online membutuhkan perangkat berupa smart phone atau perangkat computer yang terkoneksi terhadap internet. Namun ada kalanya kebutuhan minimal perangkat yang 
harus ada belum dapat dipenuhi, baik oleh guru maupun oleh siswa, hal tersebut akan berdampak kepada keberlangsungan proses pembelajaran.

Berdasarkan hasil survei diperoleh informasi bahwa tingkat kecukupan perangkat adalah 71, 05 $\%$, sedangkan sisanya 28,95\% menyatakan belum mencukupi. Hal ini harus dicarikan solusi segera agar dapat diatasi, dikarenakan pembelajaran secara daring (full online) harus tetap dilakukan, agar transformasi ilmu pengetahuan kepada siswa tidak terhenti.

5. Koneksi Internet

Koneksi internet adalah hal yang vital dan utama untuk terciptanya pembelajaran secara daring penuh, dikarenakan pembelajaran harus diakses melalui internet, tanpa ada koneksi internet, tidak aka nada interaksi yang sifatnya langsung antara siswa dengan guru. Walapun seperti buku elektronik dapat diakses dalam bentuk luring (luar jaringan). Koneksi internet di Indonesia pada umumnya, dan di Kabupaten Subang pada khususnya masih belum merata, namun sebagian besar sudah mendukung koneksi 4G.

Berdasarkan hasil survei kecukupan koneksi internet 72,36 $\%$ yang mengganggap cukup, sedangkan sisanya 27,64 \% merasa kurang, dari hasil survei tersebut dapat disimpulkan bahwa koneksi internet sudah mencukupi, walapun ada sebagian kecil yang belum. Berdasarkan hasil rapat dewan TIK nasional, bahwa tingkat pemerataan koneksi internet menjadi prioritas utama pemerintah untuk mendukung investasi provider dalam segi koneksi internet, bahkan kualitas dan kuantitas serat optik yang digunakan akan terus ditambah (Dewan TIK Nasional, 2020). Hal ini dapat menjadi angina segar untuk peningkatan kualitas pembelajaran daring kedepannya.

6. Biaya Pembelajaran Daring Pembiayaan dan kecukupan pendanaan untuk pembelajaran daring mutlak harus dapat dipikirkan, alih-alih ada efesiensi biaya dikarenakan tidak adanya biaya transpormasi, namun ada sebagian pihak yang menganggap pembelajaran daring masih mahal, mulai dari penyiapan infrastruktur, 
Didaktik : Jurnal IImiah PGSD STKIP Subang, ISSN Cetak : 2477-5673 ISSN Online : 2614-722X Volume VI Nomor 01, Juni 2020

koneksi internet (paket data internet), sampai biaya bulanan listrik yang naik. Berdasarkan hasil survei bahwa yang menyatakan biaya pembelajaran daring meningkat yaitu sebesar 69,73\%, sisanya yaitu $20,27 \%$ menganggap biaya pembelajaran daring merupakan biaya substitusi dari biaya ril ketika pembelajaran secara tatap muka.

7. Tingkat Kenyamanan Aplikasi Aplikasi adalah semacam makelar untuk menyampaikan informasi dari seorang guru kepada siswa, tanpa adanya aplikasi yang nyaman untuk digunakan, maka makna pesan yang disampaikan tidak akan dapat diterima dengan baik. Aplikasi yang disediakan sudah cukup beragam, namun lagi-lagi menuntut adanya tingkat literat digital yang memadai. Bisa jadi dikarenakan tidak menguasai teknologi menyatakan bahwa aplikasi tidak nyaman, padahal jika dioperasikan oleh orang yang menguasai teknologi, hal itu tidak terjadi. Berdasarkan hasil survei bahwa $52,63 \%$ guru menyatakan bahwa aplikasi pembelajaran online sudah cukup nyaman, namun sisanya $47,37 \%$ menyatakan masih belum nyaman.
Hasil ini berkorelasi positif dengan tingkat penguasaan literasi digital meraka.

8. Komitmen Daring Pasca Pandemi Komitmen guru untuk menggunakan pembelajaran dari pasaca Pandemi Covid-19 bersadarkan survei yaitu sekitar $65,78 \%$, hal ini dapat disimpulkan bahwa sebagian besar guru merasa "ketagihan" menggunakan pembelajaran daring, walaupun pandemi sudah berakhir. Hal ini dapat menjadi dampak positif, dikarenakan moda yang mungkin secara regulasi pasca pandemi, yaitu moda kombinasi dalam bentuk Enhanced Course, yaitu pembelajaran daring sebagai bentuk supplement materi dari pembelajaran tatap muka, sehingga ketika pembelajaran di kelas, anak setidaknya sudah mengetahui materi yang akan dipelajari, sehingga hasil belajar akan lebih meningkat.

\section{Kesimpulan}

Pembelajaran harus tetap dilakukan walaupun ditengah himpitan kesulitan COVID 19, berdasarkan delapan indikator yang diteliti, yaitu: 1) Kenyamanan Pembelajaran Masa 
Didaktik : Jurnal IImiah PGSD STKIP Subang, ISSN Cetak : 2477-5673 ISSN Online : 2614-722X

Volume VI Nomor 01, Juni 2020

Pandemi; 2) Kemampuan Literasi

Digital Guru; 3) Tingkat Adaptasi

Siswa terhadap Pembelajaran; 4)

Kecukupan Perangkat; 5) Koneksi

Internet; 6) Biaya Pembelajaran

Daring; 7) Tingkat Kenyamanan

Aplikasi; dan 8) Komitmen Daring

Pasca Pandemi, dapat disimpulkan

\section{DAFTAR PUSTAKA}

Kemendikbud. (2020). Dampak Covid-

19 Bagi Pendidikan. Jakarta : Kemendikbud

Alsa, Asmadi. (2004). Pendekatan Kualitatif dan Kuantitatif serta Kombinasinya dalam penelitian Psikologi. Yogjakarta: Pustaka Pelajar

Widodo, Dan Supriyono. (2008).

Psikologi Belajar. Jakarta: PT Rineka. Cipta.

Rosalin.(2020). Dampak Covid 19 terhadap Anak. Jakarta : Kementrian PPPA

Dewan TIK Nasional. (2020). Proyeksi

Dewan TIK Nasional terhadap Dampak Covid 19. Jakarta : Dewan TIK Nasional

Muazizah, N. M., Nurhayati, S., \& Cahyono, E. (2016). Keefektifan Penggunaan E-learning Berbasis Moodle Berpendekatan Guided Inquiry terhadap Hasil bahwa tingkat tingkat efektifitas pembelajaran sekitar $66,97 \%$, hal ini perlu ditingkatkan kembali agar pembelajaran lebih efektif guna peningkatan kualitas pembelajaran dan hasil belajar siswa.

Belajar siswa. Jurnal Inovasi Pendidikan Kimia, 10(2), 17601768

Gilster. (1997). Digital Literacy and Digital Literacies: Policy, Pedagogy and Research Considerations for Education. Sydney : James Cook University 